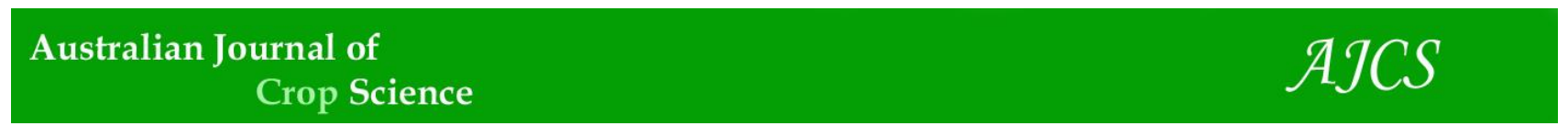

AJCS 14(12):1983-1990 (2020)

ISSN:1835-2707

doi: 10.21475/ajcs.20.14.12.2855

\title{
Foraging, spatial distribution and the effect of honeybees on soybean yield
}

\author{
Afonso H. Jung ${ }^{1}$, Clériosn R. Perini ${ }^{1}$, Ivair Valmorbida ${ }^{2}$, Alexandre Swarowsky ${ }^{3}$, Letícia Puntel ${ }^{1}$, Ricardo \\ Froehlich ${ }^{1}$, Jerson C. Guedes ${ }^{1}$
}

${ }^{1}$ Departamento de Defesa Fitossanitária, Universidade Federal de Santa Maria, Santa Maria, Brazil

${ }^{2}$ Department of Entomology, lowa State University, Ames, lowa, USA

${ }^{3}$ Engenharia Sanitária e Ambiental, Universidade Federal de Santa Maria, Santa Maria, Brazil

*Corresponding author: periniagro@gmail.com

\begin{abstract}
The soybean is the most cultivated grain crop in Brazil and there are many efforts to protect visitor pollinators, especially honeybees. The understanding of honeybee behavior on soybean fields is important to growers to apply integrated pest management strategies to avoid harm the pollinators. The European bee (Apis mellifera Linnaeus, 1758 (Hymenoptera: Apidae)) is a social bee, with European origin, whose the worker length is $12 \mathrm{~mm}$ to $13 \mathrm{~mm}$ with darker chest hairs. In this sense, foraging hours of Apis on soybean, its spatial distribution, the effect of pollination on soybean yield and the effect of insecticides on honeybee behavior were investigated. Two experiments were carried out. The first experiment was performed in a soybean field with 79 sampling points and four insecticide treatments to understand the spatial distribution of honeybees. In addition, foraging behavior of honeybees was evaluated hourly from 7:00am to 7:00pm randomly on 40 sampling points. The second experiment was carried out in cages with and without honeybees to quantify the effect of pollination on soybean yield under spray of chemical insecticides. Four hives with Africanized honeybees (A. mellifera) were set around the area. The hives had approximately six to eight brood frames and two to four food frames. Insecticides were sprayed as diferent treatments. The first experiment showed that honeybees prefer to forage on soybean flowers from 10:00am to 1:00pm and have random distribution. The use of $A$. mellifera as a pollinator did not increase the yield of soybean. Besides the particular manner of experiment's conduction, the information of foraging behavior of honeybees, the pollination effect on soybeans yield and the effect of insecticides on honeybees are prudently discussed and some implication for soybean producers are also carefully addressed to avoid insecticide applications to harm pollinators. It is important to understand that the effect of pollination on yield of soybean depends on environmental conditions, cultivars, the effect of caging plants, and the abnormally high concentration of bees in the cages.
\end{abstract}

Keywords: Apis mellifera; Glycine max; pollination; behavior; ecology; insecticide.

Abbreviations: WB_caged soybean with honeybees; NB_caged soybean without honeybees; FVP_uncaged soybean; NPK_nitrogenphosphorus-potassium; IPM_Integrated Pest Management.

\section{Introduction}

Soybean (Glycine max (L.) Merril) is the major crop in Brazil, occupying $50 \%$ of cultivated crop land (Conab, 2019). However, the foraging behavior of honeybees and its effect as a pollinator remains uncertain. Soybean is an autogamous species with both stamens and pistil enclosed within the corolla (Sediyama, 1985). Pollen release and pistil reception occur before corolla opening for most soybean varieties, a process known as cleistogamy (Muller, 1981). Due to flower anatomy characteristics, soybean is considered selfpollinating (Delaplane and Mayer, 2000), such that crosspollination between flowers is less than $1 \%$ (Schuster et al., 2007). Studies on the effects of honeybee pollination on soybean have given divergent results. For example, Southwick and Southwick (1992) found no yield loss for soybean in the absence of honeybees or any replacement insects as pollinators. Conversely, increases in soybean yield with the presence of honeybees also have been reported (Erickson, 1975; Abrams et al., 1978; Erickson et al., 1978; Kettle and Taylor, 1979, Mason, 1979; Robacker et al., 1983; Chiari et al., 2005; 2008, Milfont et al., 2013; Kengni et al.,
2015; Blettler et al., 2018). These contrasting results seem to be dependent on methodologies used in each experiment, soybean varieties, crop management, and environmental conditions. Furthermore, the unnatural environment inside the cages built to keep the bees during the experiments may affect development of soybean plants, which makes it difficult to compare artificial research models to a natural pollination process.

Foraging behavior of pollinators during the plant developmental stages, especially during flowering stages, is a key issue in soybean production systems. The biology of honeybees, together with climate factors including temperature, humidity and wind speed, are known to affect their foraging on flowers (Malerbo-Souza and Silva, 2011). For instance, the foraging activity of Apis mellifera adansonii Linneaus, 1758 (Hymenoptera: Apidae) is influenced by temperature and hygrometry throughout the flowering period, with a peak of activity between 01.00 p.m. and 02.00 p.m. (Kengni et al., 2015). Temperature also influences the foraging behavior of $A$. mellifera during the daytime and 
throughout the year (Malerbo-Souza and Silva, 2011). In addition, regarding the ecological concept of population dynamics of insects, the spatial and time distribution patterns of $A$. mellifera in soybean fields are not understood. Regardless of the fact that the distribution models of wild and managed pollinators are based on crop location, their foraging distance and dispersal functions are empirically derived (Lonsdorf et al., 2009; Polce et al., 2013), and not applicable from one field to another or across crop types, including commodities. Therefore, the relationship between spatial and time distribution has an important role on the ecology and consideration of sampling methods for honeybees in soybean fields.

In cropland areas, several factors are known to affect pollination services, notably farm management practices (Nicholson et al., 2017, Pufal et al., 2017). Among these practices, insecticides have been shown to affect the foraging of honeybees (Bortolotti et al., 2003). Therefore, the use of environmentally friendly pesticides and repellent agents to treat soybeans may cause less harm to pollinators (Fagúndez et al., 2016), and perhaps even the possibility to avoid the use of chemical pesticides during the flowering period, based on honeybee foraging behavior. Insecticides are frequently used in soybean production systems in Brazil to control pests and prevent yield loss. Some of these insecticides used in soybean fields have been banned in other countries, including thiamethoxam and imidacloprid. They are still registered and recommended by the Ministry of agriculture, livestock and supply (MAPA http://agrofit.agricultura.gov.br/agrofit_cons/principal_agro fit_cons) to control key pests in Brazil, especially against stink bugs and Bemisia tabaci in soybeans, cotton and maize. It is apparent that management of sucking pests in Brazil requires other new control methods that efficiently reduce the risk of damage to other useful insects. However, new methods are not available to growers yet. Based on these issues related to insect pollinators, we conducted experiments to assess the foraging behavior of $A$. mellifera on soybean flowers during the day and its spatial distribution within soybean fields sprayed with insecticides or not sprayed. In addition, we also evaluated the effect of honeybee pollination on soybean yield under differing pollination systems and insecticide spray treatments.

\section{Results}

\section{Experiment I: Foraging time and spatial distribution of Apis mellifera on soybean with and without chemical insecticides sprays}

The preferable period of foraging for nectar and pollen during the day in soybean flowers was between 10:00am and 1:00pm (Figure 3), significantly different between time of evaluation (Supplementary 3). However, foraging activity began around 9:00am and declined around 02:00pm to 03:00pm. Peak foraging was at 12:00pm, ranging from 4-9.5 bees per sample point, within the five minutes of sampling. After 3:00pm and during periods of low temperature, especially early in the morning and evening, only several bees were observed near the hives, and these bees were not foraging. In addition, the foraging time of bees on soybean flowers was similar regardless of the soybean growth stage evaluated (Supplementary 4).

At beginning of the bloom stage of soybean plants, when open flowers began to appear, there was an insignificant number of $A$. mellifera foraging in the field, compared to the sampling at full bloom stage (Figure 4). The highest number of $A$. mellifera foraging was at the full bloom stage of soybean plants, with bees present in the entire sampled area, concurrent with greater availability of open flowers. A higher density of bees was observed in the neighborhood of the hives (50-150 $\mathrm{m}$ from beehives), indicating that the placement of beehives influenced the spatial distribution of bees on soybean fields (Fig 4).

The soybean plots sprayed with insecticides (thiamethoxam + lambda-cyhalothrin, imidacloprid + beta-cyfluthrin, and acephate) at the full bloom stage had no measurable effect on distribution of $A$. mellifera. The two maps illustrating both the immediate after-effect ( 3 days) and a later aftereffect (11 days) of insecticide spray time, show that the distribution pattern and number of $A$. mellifera on soybean field was not affected by the use of insecticides (Figure 4). However, we have to consider the possibilities of bees flying around the soybeans into the experimental area, and viceversa, because the beehives were installed on the border of perimeter.

Spatial distribution of bees in the soybean field (Figure 4) was classified as a random distribution with the absence of spatial dependence. The value of the nugget effect ranged from 0.39-1.14 and the sill parameter ranged from 0.10-1.21 (Supplementary 2 and 6). For the most semivariograms, it was not possible to adjust any model of spatial variability because of the absence of spatial dependence, since the values of the nugget effect were higher than those of the sill parameter. Exception was found at full bloom stage prior to insecticides spray (Supplementary 6). It was not possible to use the classification of Cambardella et al., (1994) for spatial dependence analysis in the range of values obtained for the nugget effect and sill parameter. Cambardella's classification considers a strong spatial dependence for a semivariogram that has a nugget effect value $<25 \%$ of sill parameter, or moderate when it ranges between 25 and $75 \%$, or weak when is $>75 \%$ of sill parameter.

Experiment II: Pollination effect of Apis mellifera on soybean yield under different pollination systems and use of chemical insecticides

There was no interaction between presence/absence of honeybees and insecticide treatments (Supplementary 5A) and each factor was analyzed separated. The yield of treatments is shown on Figure 5. The uncaged treatment (open to natural pollinators) had a significantly greater yield when compared to caged treatments, with and without honeybees (Table 1). The average yield of the uncovered area was $349.44 \mathrm{~g} \mathrm{~m}^{-2}$, which was greater than either of the caged areas by a factor of $16.5 \%$ for the sample with bees, and greater by a factor of $15.6 \%$ for the area without bees. No significant yield differences were observed between caged plots with or without honeybees $\left(291.73 \mathrm{~g} \mathrm{~m}^{-2}\right.$ and $294.91 \mathrm{~g} \mathrm{~m}^{-2}$, respectively). Comparing the yield averages between insecticide treatments, we found the lowest yield on untreated control plots $\left(263.42 \mathrm{~g} \mathrm{~m}^{-2}\right)$ differing from the plots that received an insecticide spray (Table 1 ).

For the variable 100-seed weight, there was interaction between the presence/absence of pollinators and insecticide treatments $(P=0.02187)$ (Supplementary $5 \mathrm{~B}$ ) only on the uncovered area (Table 2). Cages without honeybees and with application of insecticides resulted in a higher weight of 100 seeds (Thiamethoxam + Lambda-cyhalothrin - 18.4025g, Imidacloprid + Beta-cyfluthrin - 16.7550g and Acephate - 
$17.2575 \mathrm{~g}$ ), differing from untreated control plots (14.9250g). Soybeans caged with honeybees presented the higher weight of 100 seeds for the insecticide Thiamethoxam + Lambda-cyhalothrin (16.4175g), differing statistically from Acephate (14.5800g) and untreated control (14.1700g). Analyzing the mean data of each insecticide, we found the lowest weight of 100 seeds on untreated control (15.5150g) (Table 2), which was statistically different from Thiamethoxam + Lambda-cyhalothrin (17.5866g) and Imidacloprid + Beta-cyfluthrin (16.9833g).

The open field plots presented the highest 100 -seed weight for all insecticides and untreated control, resulting an average of $17.8850 \mathrm{~g}$. The caged plots with bees had the lowest 100-seed weight (15.1450g), independently from treatments. These findings indicate that the soybean seed weight has a restricted effect by pollination under covered areas. It appears to be more related to the reduced damage of insect-pests due to the efficacy of some insecticides in controlling these pests.

\section{Discussion}

Our study provides some suitable information on the foraging behavior of honeybees among day period, from 07:00am to 07:00pm, at soybean bloom stage. On the other hand, careful insights of insecticide effects on honeybees and the effect of pollination on soybean yield could be taken, besides the particular manner of experiment's conduction. Its implication for soybean producers could be addressed in regard to understand the honeybee behavior to use precautionary principles for insecticide applications during the blooming period of soybeans, considering the good practice of Integrated Pest Management (IPM), in order to be less harmful on bees/pollinators and also to protect the crop against pest damages.

The peak time of pollen and nectar collection on soybean flowers was between 10:00am to $1: 00 \mathrm{pm}$, very similar to other studies that evaluated honeybee foraging on soybean plants. Foraging activity in soybeans has been observed to peak between 11:00am to 12:00pm (Milfont, 2012), $11: 00 \mathrm{am}$ to $1: 00 \mathrm{pm}$ (Fávero and Couto., 2000), and at 12:30pm (Blettler et al., 2018). It is known that below 13으 foraging is limited, but over $19{ }^{\circ} \mathrm{C}$ it increases to a relatively high level (Keogh et al., 2005). These results demonstrate that temperature plays an important role in defining hours, in which the honey bee foraging activity occurs in soybean fields, especially on sunny days.

Our data confirm that pesticide application should be avoided from 9:00am to 3:00pm because of the presence of honeybees in a soybean field during the hottest mid-day hours. The best time to apply insecticides is at dusk, night, or early in the morning when the bees are not foraging (Jay, 1986). The time of application of insecticides should aim to have the least impact on pollinators that are visiting soybean flowers. Nevertheless, we encourage no insecticide applications during soybean bloom (flowers opened) unless strictly necessary. This minimizes the risk of exposure of pollinators in soybean fields to lethal and sublethal concentration of insecticides.

The average number of bees visiting soybean flowers was very low (6-10 bees per sample point) even with the placement of hives on the edge of the soybean field. The floral biology (e.g. flower size, cleistogamy, nectar production, flower abundance, and flowering sequence) are directly associated with the attraction effect on bees
(Erickson, 1975). Cross-pollination of soybean flowers is less than one percent (Schuster et al., 2007), thus the pollen available for bee foraging is almost absent. The quantity and quality of pollen and nectar produced by the flowers is very poor (Jaycox, 1970) and this explains the generally low number of bees visiting soybean flowers.

Soybean cultivars planted in Rio Grande do Sul have a flowering period of approximately 5 to 15 days (Zanon et al., 2016), with sequential, not simultaneous, opening of blooms. Therefore, soybean plants provide a short period of availability of pollen and nectar from the opening flowers in layers on soybean canopy. These sequential flower layers might be an inefficient source of pollen and nectar to honeybees with a width-time distribution of only a few flowers. In contrast, pollinators can find richer sources of pollen and nectar in flowers growing nearby within forests, native vegetation, and cultivated plants (Lengler, 1999). In Rio Grande do Sul, a major honey producer in Brazil, bees seek pollen and nectar mainly on native vegetation, native trees, and cultivated Eucaliptus spp. (Coelho, 2011). Since bees have other options for foraging, this may account for the low occurrence of bees on soybean flowers even when beehives are placed on the edge of a soybean field.

In southern Brazil, beekeepers do not locate beehives along borders of soybean fields, as we did in this experiment. We tested an uncommon concentration of bees, higher than a natural occurrence of pollinators on soyean field (four beehives allocated around an area of 19.7ha), and found no effects on behavior or repellency, when strips of insecticides were applied to the experimental area. Additionally and more significantlly, no signs of dead bees at each sample point and in the neighborhood of hives were seen. However, long-term effects of the insecticides used were not evaluated, and insecticides to control soybean pests may change each growing season on the basis of pest occurrence and pressure. Thus, regardeless of the lack of a short-term effect observed in this experiment, further research including other pesticides and evaluation of behivee health over the year must be conducted. Some works report a chronic exposure to pesticides (e.g. neonicotinoid and pyrethroid) prejudices foraging behavior (efficiency to collect pollen) and results in mortality of worker honeybees (Gill et al., 2012). In addition, declines of wild and managed bees are also substantially involved with other factors besides pesticides, including parasites and the loss of habitat that reduce floral resources (Goulson et al., 2015).

Although there was no interaction between the pollination and insecticide treatments for soybean yield (Figure 5), the uncovered area had the highest mean yield (Table 1), comparable to means of seed weight (Table 2). These findings raise some possibilities to explain the highest yield and seed weight in uncovered area free of pollination, compared to caged areas. First point, the uncovered areas have the maximum sunlight incidence on soybean canopy, compared to caged areas covered with a voile fabric, and the plants are more photosynthetically active. Secondly, we can point the possibility of a higher infestation of pollinators inside the cages from each beehive, which could damage the flowers instead of pollinating them. Third point, unlike the second point, the area opened to pollinators probably had anemophily from honeybees and other insects at a balanced amount of insect density. Fourth point, the lowest yield and seed weight on untreated control plots, compared to insecticides treatments, seems to be due to pest damage, 
Table 1. Mean of soybean yield $\left(\mathrm{g} \mathrm{m}^{-2}\right)$ on treatments of pollination options and insecticide application.

\begin{tabular}{lllll}
\hline & Cage with honeybees & Cage without honeybees & Uncovered area & Untreated control \\
\hline Mean yield & $291.73 \mathrm{~b}$ & $294.91 \mathrm{~b}$ & $349.44 \mathrm{a}$ & \\
\hline & Thiamethoxam + lambda-cyhalothrin & Imidacloprid + Beta-cyfluthrin & Acephate & $263.42 \mathrm{~b}$ \\
Mean yield & $336.77 \mathrm{a}$ & $327.92 \mathrm{a}$ & $320.01 \mathrm{a}$ & \\
\hline
\end{tabular}

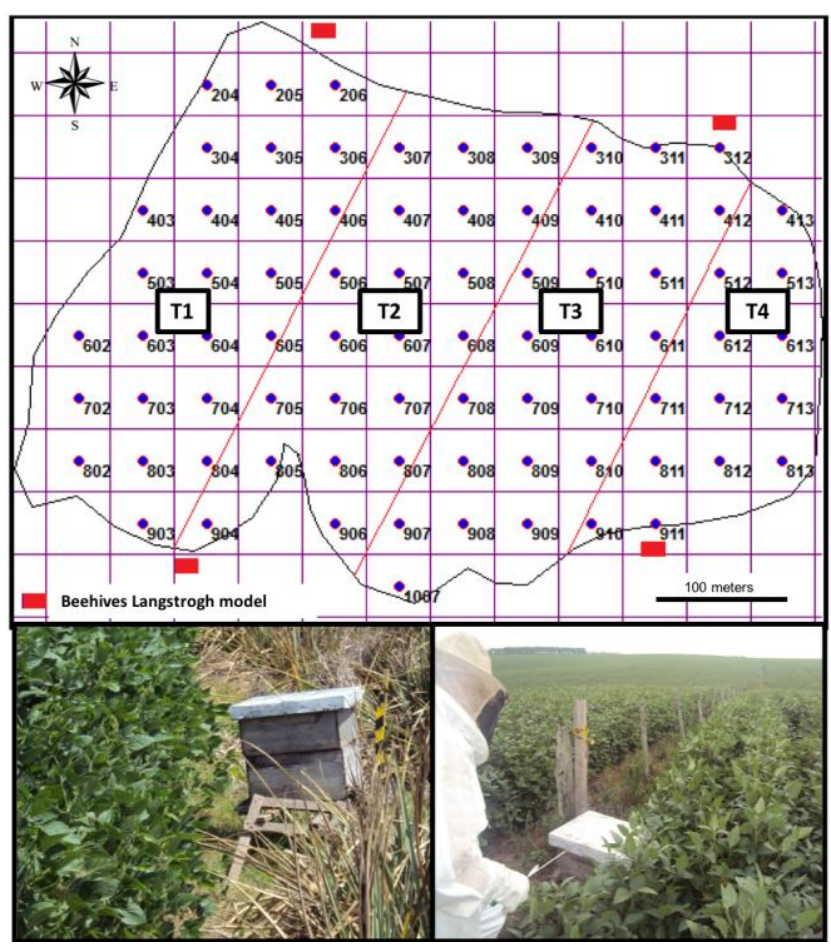

Fig 1. Map of the experimental area with a regular grid $(50 \mathrm{~m} \times 50 \mathrm{~m})$, sampling points, strips of insecticide treatments ( $\mathrm{T} 1, \mathrm{~T} 2$ and T3) and untreated plot (T4) separated by red lines, and indication of beehive's disposal around the experimental area

Table 2. Soybean 100-seed weight (g) from samples with insecticide application and presence of Apis mellifera.

\begin{tabular}{|c|c|c|c|c|c|}
\hline \multirow[b]{2}{*}{ Honeybees } & \multicolumn{4}{|c|}{ Insecticides applied } & \multirow[b]{2}{*}{ Mean } \\
\hline & $\begin{array}{l}\text { Thiamethoxam+ lambda- } \\
\text { cyhalothrin }\end{array}$ & $\begin{array}{l}\text { Imidacloprid+ Beta- } \\
\text { cyfluthrin }\end{array}$ & Acephate & Untreated control & \\
\hline Cage with honeybees & $16.4175 \mathrm{bA}^{*}$ & $15.4125 \mathrm{bAB}$ & $14.5800 \mathrm{bB}$ & $14.1700 \mathrm{bB}$ & $15.1450 \mathrm{c}$ \\
\hline Cage without honeybees & $18.4025 \mathrm{aA}$ & $16.7550 \mathrm{bA}$ & $17.2575 \mathrm{aA}$ & $14.9250 \mathrm{bB}$ & $16.8350 \mathrm{~b}$ \\
\hline Uncovered area & $17.9400 \mathrm{abA}$ & $18.7825 \mathrm{aA}$ & $17.3675 \mathrm{aA}$ & $17.4500 \mathrm{aA}$ & $17.8850 \mathrm{a}$ \\
\hline Mean & $17.5866 \mathrm{~A}$ & $16.9833 \mathrm{AB}$ & $16.4016 \mathrm{BC}$ & $15.5150 \mathrm{C}$ & \\
\hline
\end{tabular}

* Mean values followed by the same lowercase letters in each column, and uppercase letters in each line, do not differ significantly at $\mathrm{P}<0.05$ by the Tukey test.

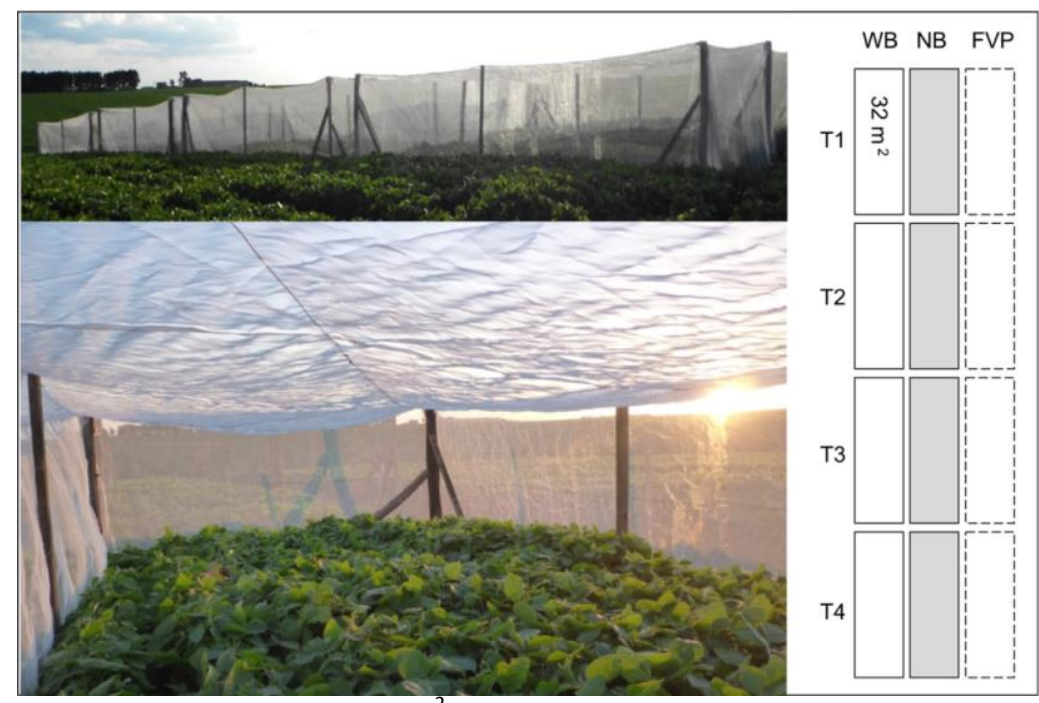

Fig 2. Pollination cages used in the experiment sized $32 \mathrm{~m}^{2}$ (length $8 \mathrm{~m}$, width $4 \mathrm{~m}$, height $2 \mathrm{~m}$ ). Insecticide treatments in the vertical side and WB - cages with beehives, NB - cages with no beehives and FVP - free visiting pollinators. 


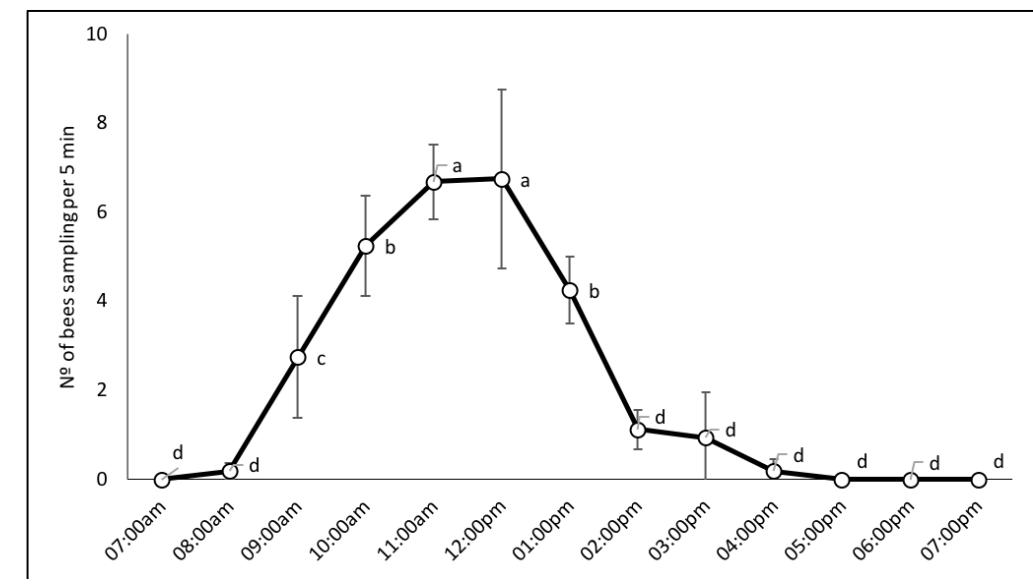

Fig 3. Number of honeybees (Apis mellifera) foraging in soybean flowers during the day, from beginning bloom to beginning pod stages.
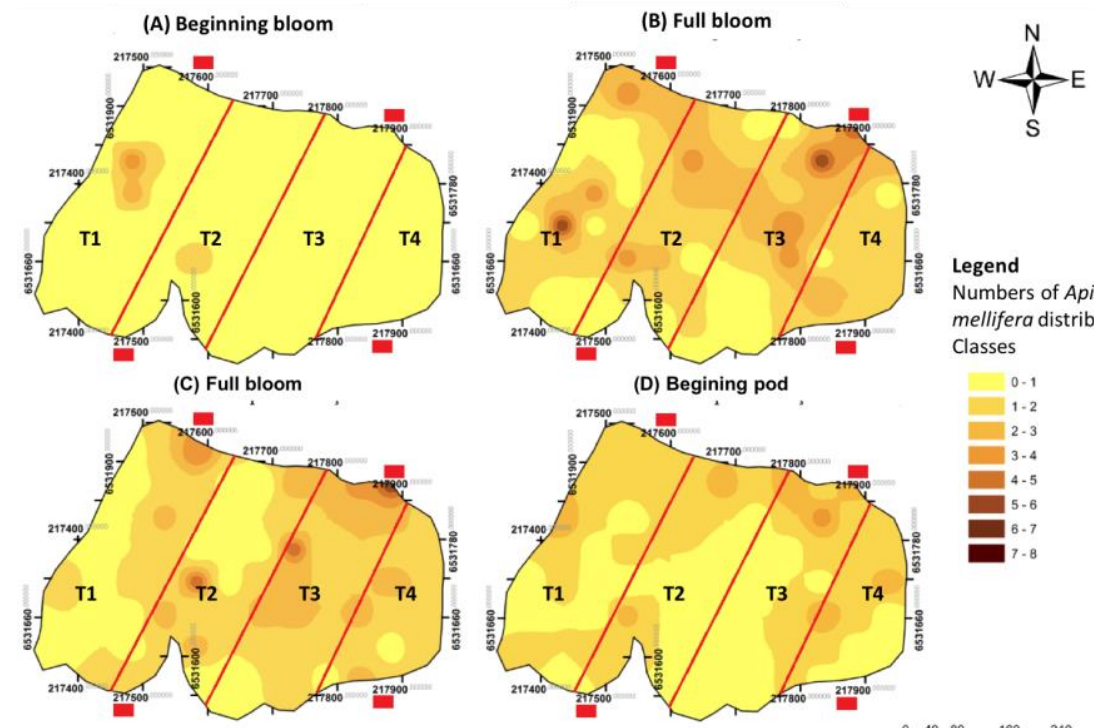

\section{Numbers of Apis}

mellifera distribution

Classes

$0-1$
$1-2$

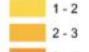

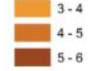

$\mathbb{7}_{7-8}^{5-6}$

Beehives Langstrogh model

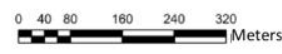

Fig 4. Spatial-temporal distribution of honeybees (Apis mellifera) from beginning bloom to beginning pod stages. Strips indicate insecticide treatments (T1, T2 and T3) and untreated plot (T4) separated by red lines.

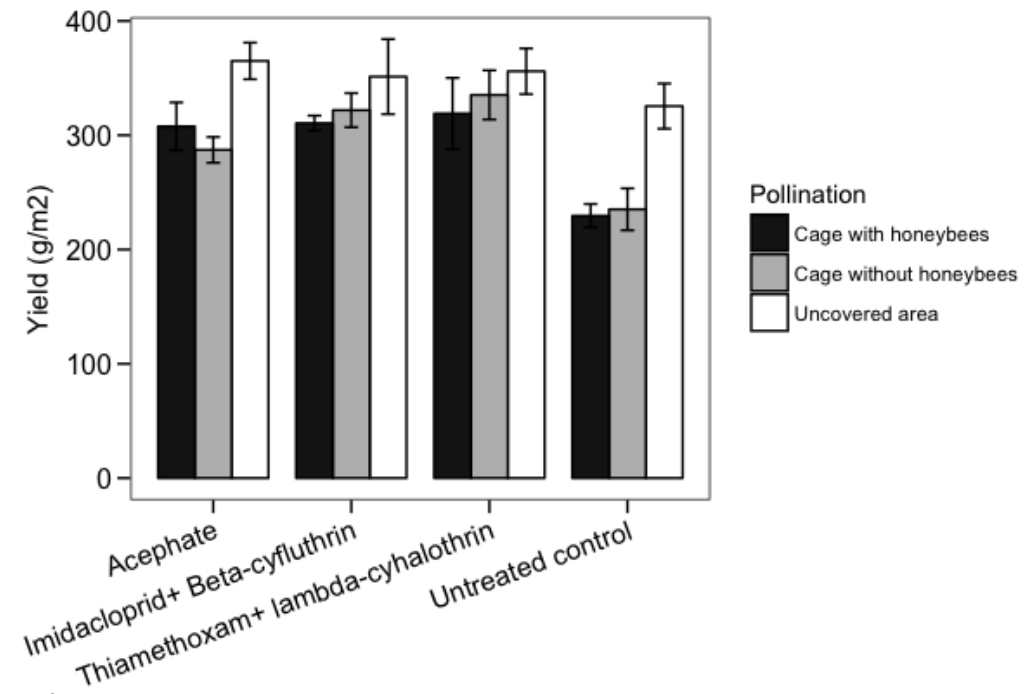

Fig 5. Soybean yield $\left(\mathrm{g} \mathrm{m}^{-2}\right)$ under insecticide application and presence of Apis mellifera. Means and its interaction are not significantly different $(P>0.05)$. 
because no spray was applied in these areas to control insect-pests.

Previous research has demonstrated beneficial effects on soybean yield due to the presence of honeybees. Soybean yield was greater in caged samples with bees and open field samples (37.84\% and $41.39 \%$ greater, respectively), compared to caged plots without honeybees (Chiari et al., 2008). Soybean seed production (soybean variety BRS 133) was $57 \%$ higher in fields open to pollinators compared to caged plots without bees (Chiari et al., 2005), and soybean flowers visited by honeybees had greater production of viable seeds (66.17\%) (Ribeiro and Couto, 2005). A more recent study in Argentina over two soybean growing seasons demonstrated that soybean yield increases in plots with soybean plants open to pollinators compared to caged plants. However, this positive effect was observed on caged plots only in one year, and environmental conditions seemed to be a strong determinant of the degree to which soybeans benefit from pollinators (Blettler et al., 2017). These previous results are in accordance to our findings and the points raised above explain the possibilities of higher yields and 100 -seed weight at uncaged plots.

Soybean is considered a self-pollinating species that receives no benefit from the presence of pollinators (Milum, 1940, Rubis, 1970), probably because the process of pollination is completed 24 hours before the opening of soybean flowers (Carlson and Lersten, 2004). Also, not all soybean varieties are attractive to honeybees, apparently because of genetic and environmental factors (Erickson, 1975, Issa et al., 1980, Robacker et al., 1983). Furthermore, the variety used in our experiment (determinate cultivar) has a short period of blooming for bees to pollinate and affect on soybean yield. Maintaining of a high honeybee population in a small area, with a limited number of flowers, is not representative of normal field conditions (Milfont, 2012). The contradictory results and discussions regarding soybean pollination will be better understood if an entire environmental condition in soybeans fields is taken into consideration (Chiari et al., 2008).

\section{Materials and Methods}

\section{Experimental design}

The experiments were conducted during the 2012/13 soybean growing season in Hulha Negra city in the state of Rio Grande do Sul, Brazil ( $31^{\circ} 18^{\prime} 52^{\prime \prime} \mathrm{S}$ and $53^{\circ} 58^{\prime} 02^{\prime \prime} \mathrm{W}$; alt. $230 \mathrm{~m}$ above sea level). Sowing of A 6411 RG soybean variety (determinate), maturity group 6.2 (135 days) was carried out on December 14, 2012 at a 45-cm row spacing and fertilized at the same time $\left(23 \mathrm{~g} \mathrm{~m}^{-2}\right.$ of NPK 05-18-18). The following management practices were performed to control weeds: pre-sowing - Roundup 720 WG, 0.2 $\mathrm{g} \mathrm{m}^{-2}$, glyphosate, + Clorim 250 WG, $0.008 \mathrm{~g} \mathrm{~m}^{-2}$, chlorimuron-ethyl; postemergence - V4 - Roundup 720 WG, $0.2 \mathrm{~g} \mathrm{~m}^{-2}$, glyphosate; to control caterpillars: V4 and R1 - Dimilin 800 WG, $0.008 \mathrm{~g} \mathrm{~m}^{-2}$, diflubenzuron; to control diseases - R1, R5.1 and R6 - Priori Xtra $200+80 \mathrm{SC}$, azoxystrobin+ cyproconazole, $3 \times 10^{-5} \mathrm{~L} \mathrm{~m}^{-2}$. These products were applied with a self-propelled sprayer at a flow rate of $0.02 \mathrm{~L} \mathrm{~m}^{-2}$. The experimental area was surrounded by soybeans and fairway from it $(2 \mathrm{~km})$ there were a native pasture and eucalyptus plantation.
Experiment I: Foraging time and spatial distribution of Apis mellifera on soybean sprayed with insecticides

The perimeter of a $197000 \mathrm{~m}^{2}$ experimental area was demarcated with a Garmin GPS, with an interface for a palmtop. The software CR-Campeiro was used to demarcate 79 sampling sites on the experimental area at $50 \mathrm{~m}$ away from each other (grid of $50 \mathrm{~m} \times 50 \mathrm{~m}$ ), represented by dots on Figure 1 . On February 15, 2013, at the soybean pre-bloom stage, four beehives with Africanized honeybees (A. mellifera) were set around the area. The hives had approximately six to eight brood frames and two to four food frames. Furthermore, four strips of land $150 \mathrm{~m}$ wide were marked off where insecticide treatments were sprayed.

The treatments were sprayed on March 2, 2013, 15 days after the installation of bee colonies, as follows: T1Engeo $^{\text {TM }}$ Pleno $141+106 \mathrm{SC}, 0.02 \mathrm{~mL} \mathrm{~m}^{-2}$, thiamethoxam + lambda-cyhalothrin; T2- Connect $100+12,5 \mathrm{SC}, 0.1 \mathrm{~mL} \mathrm{~m}^{-2}$, imidacloprid + beta-cyfluthrin; T3- Orthene 750 BR 750 PS, $0,07 \mathrm{~g} \mathrm{~m}^{-2}$, acephate; and T4- untreated control. The sprays were applied with a self-propelled sprayer at a flow rate of $0.02 \mathrm{~L} \mathrm{~m}^{-2}$. These insecticides and the times of spray selected are in agreement with pest management practices on soybeans, because they are the most sprayed during the reproductive stage of soybeans to manage insect-pests, in particular stink bugs.

Foraging time and spatial distribution of bees were determined weekly from the beginning to the end of the soybean flowering stages (Fehr and Caviness., 1977). The first two samplings ( $A$ and $B$ ) were made prior to insecticide application and the last two ( $C$ and $D)$ were performed after the application (Supplementary 1). The number of honeybees foraging in the soybean flowers was sampled following Milfont. (2012) methodology, by visual counting (stopped at a point about $2.5 \mathrm{~min}$ covering a radius of $1 \mathrm{~m}$ $2 \mathrm{~m}$ ) and with an entomological sweep net (10 sweeps that took about $2.5 \mathrm{~min}$ to sweep and to count bees collected), completing the evaluation in five minutes. In the foraging time, the sampling was done hourly from 7:00am to 7:00pm by seven people randomly on 40 sampling points. This sampling was performed at (A) R1 - 02/21/13, (B) R2 $02 / 28 / 13$, (C) R2 - 03/04/13, and (D) R3 - 03/12/13. Each evaluation date was considered as one replicate on time. Total data of each site found during 5 minutes of sampling procedures was used to ANOVA analysis in SISVAR (version 5.6) (Ferreira, 2011) and the means compared with the grouping test Scott-Knott $(P<0.05)$.

The evaluation of spatial distribution was performed a day after from dates described above, before and after spray. The number of honeybees was evaluated also during five minutes with seven evaluators during the day time (from 11:00am to $1: 00 \mathrm{pm}$ ) at those 79 sampling sites, to obtain semivariograms and to assess the spatial distribution parameters of honeybees in the experimental area. From this, statistical models were adjusted for subsequent interpolation of variables and population maps were built by ordinary kriging with the software ArCGIS 9.3.

Experiment II: Pollination effect of Apis mellifera on soybean yield under different pollination systems and with and without chemical insecticides

A two-factorial experiment was performed in a completely randomized design at a homogeneous area (free of soil, 
cultivar and environmental variation) in the soybean field, where factor $A$ was the presence of honeybees and Factor B was the use of insecticides. Eight cages of $32 \mathrm{~m}^{2}$ were built before the soybean bloom stage (length $8 \mathrm{~m}$, width $4 \mathrm{~m}$, and height $2 \mathrm{~m}$ and due to the size was considered one cage for each treatment) to make the manipulation of hives inside the cages possible, instead to using small replicates (Figure 2).

The treatments of Factor A were as follows: (1) caged soybean with honeybees (WB) - one beehive on each cage; (2) caged soybean without honeybees (NB); and (3) uncaged soybean (FVP) - free to wild visitor pollinators and honeybees. One beehive was placed inside of each cage of caged soybean with honeybees when $10-15 \%$ of plants had begun to bloom (February 15, 2013). Each hive had approximately 5,000 Africanized honeybees, with high purity and uniform population, consisting of three to four broods and one to two food frames. At the beginning of the R3 growth stage, beehives and cages were removed, and stakes were used to mark the area of each treatment. The treatments of Factor B were applied inside the cages with and without honeybees and over uncaged soybean. Insecticides were chosen based on current registration for soybeans in Brazil: T1 - Engeo ${ }^{\mathrm{TM}}$ Pleno $141+106 \mathrm{SC}, 0.02 \mathrm{~mL}$ $\mathrm{m}^{-2}$ (thiamethoxam + lambda-cyhalothrin); T2 - Connect $100+12,5 \mathrm{SC}, 0.1 \mathrm{~mL} \mathrm{~m}^{-2}$ (imidacloprid + beta-cyfluthrin); T3 Orthene $750 \mathrm{BR}^{\circ} 750 \mathrm{PS}, 0.07 \mathrm{~g} \mathrm{~m}^{-2}$ (acephate); and T4 untreated. Each treatment was sprayed at the soybean R2 stage with a $\mathrm{CO}_{2}$-pressurized backpack sprayer equipped with four Teejet XR 110.015 nozzles (spaced $0.5 \mathrm{~m}$ apart), and a flow rate of $0.015 \mathrm{~L} \mathrm{~m}^{-2}$.

To quantify the soybean yield, four replicates of $3 \mathrm{~m}^{2}$ in the middle of each experimental cage were harvested. In addition, four replicates of 100 grains from each cage were weighed and evaluated to obtain the average weight of 100 grains (g). Statistical analyses were performed using the software Assistat (7.7 Beta Version; 2009). Data were analyzed by ANOVA, and the means were separated by Tukey's test with a significance level of $P<0.05$.

\section{Conclusion}

Our findings corroborate with soybeans reproductive physiology, where no response of soybean yield occurred from pollination, except for uncovered area that have free visiting of pollinators and free sunlight incidence over soybeans canopy. In regards that soybean is an autogamous species, we could not see a clear yield advantage, even with high pollinator densities. Even more, the overall effect of pollination on yield of soybean depends on environmental conditions, cultivars, the effect of caging plants, and the abnormally high concentration of bees in cages.

\section{Acknowledgements}

We would like to thank the beekeeper Gerson Fensterseifer and his team for lending of hives, help in conducting these experiments and instruction in the beekeeping field. We acknowledge the financial scholarship from Conselho Nacional de Desenvolvimento Científico e Tecnológico (CNPq) for the first author.

\section{References}

Abrams RI, Edwards CR, Harris T (1978) Yields and crosspollination of soybeans as affected by honeybees and alfalfa leaf cutting bees. Amer Bee J. 118(8), 555-556.

Blettler DC, Fagúndez GA, Caviglia OP (2018) Contribution of honeybees to soybean yield. Apidologie. doi: 10.1007/s13592-017-0532-4.

Bortolotti L, Montanari R, Marcelino J, Medrzychi P, Maini S, Porrini C (2003) Effects of sub-lethal imidacloprid doses on the homing rate and foraging activity of the honey bees. Bull Insectol. 56: 63-67.

Cambardella CA, Moorman TB, Novak JM, Parkin TB, Karlen DL, Turco RF, Konopka AE (1994) Field-scale variability of soil properties in central lowa soils. Soil Sci Soc Am J. 58(6):1501-1511.

Carlson JB, Lersten NR (2004) Reproductive morphology. In: Boerma, R. and Specht, J. E. (Eds.), Soybeans: improvement, production, and uses (3rd ed.). CSA, CSSA, SSSA, pp59-95.

Chiari WC, Toledo VAA, Hoffmann-Campo CB, RúvoloTakasusuki MCC, Toledo TCSOA, Lopes TS (2008) Polinização por Apis mellifera em soja transgênica (Glycine max (L.) Merril) Roundup Ready cv. BRS 245 RR e convencional cv. BRS 133. Acta Sci Agron. 30(2), 267-271.

Chiari WC, Toledo VAA, Rúvolo-Takasusuki, MCC, Oliveira AJB, Sakaguti ES, Attencia VM, Costa FM, Mitsui MH (2005) Pollination of soybean (Glycine $\max$ (L.) Merrill) by honeybees (Apis mellifera L.). Braz Arch Biol Technol. 48(1), 31-36.

Coelho JCJ (2011) A cadeia de produção do mel no Rio Grande do Sul: A organização e a Governança nas transações dos Apicultores associados à APISMAR. Universidade Federal de Santa Maria. Santa Maria, Dissertação de Mestrado.

Conab (2019) Acompanhamento da safra brasileira de grãos. https://www.conab.gov.br/ Accessed 10 March 2019.

Delaplane, K. S., Mayer, D. F. (2000) Crop pollination by bees. CABI Publishing, New York

Erickson, E. H. (1975) Effect of honey bees on yield of three soybean cultivars. Crop Sci. 15(1), 84-86.

Erickson, E. H., Berger, G. S., Shannon, J. G., Robins, J. M. (1978) Honey bee pollination increases soybean yields in the Mississippi Delta Region of Arkansas and Missouri. J Econ Entomol. 71(4), 601-603.

Fávero AC, Couto RHN (2000) Polinização entomófila em soja (Glycine max L. var. FT 2000), Congresso Brasileiro de Apicultura 13. Florianópolis. Anais Confederação Brasileira de Apicultura. UFSC.

Fehr WR, Caviness CE (1977) Stages of soybean development. lowa: lowa State University, Ames, pp12. (Special report 80).

Freitas BM, Imperatriz-Fonseca VL (2004) Economic value of Brazilian cash crops and estimates of their pollination constrains. Food and Agriculture Organization Report, Universidade de São Paulo, São Paulo. 2, 1-4.

Giannini TC, Cordeiro GD, Freitas BM, Saraiva AM, Imperatriz-Fonseca VL (2015) The dependence of crops for pollinators and the economic value of pollination in Brazil. J Econ Entomol. 108(3), 849-857.

Gill RJ, Rodriguez OR, Raine NE (2012) Combined pesticide exposure severely affects individual and colony-level traits in bees. Nature. 491, 105-109. 
Goulson D, Nicholls E, Botías C, Rotheray EL (2015) Bee declines driven by combined stress from parasites, pesticides, and lack of flowers. Science. 347(6229), 1255957-1 - 1255957-9.

Issa MRC, Velocci MEP, Gonçalves LS, Soares AEE (1980) Ensaio de polinização da soja (Glycine max) por abelhas (Apis mellifera), Congresso Brasileiro de Apicultura 5. Anais. Viçosa UFV, 430p.

Jay SC (1986) Spatial management of honey bee on crops. Ann Rev Entomol. 31: 49-65

Jaycox ER (1970) Ecological Relationships between honey bees and soybeans. Amer Bee J. 110(8), 306-385.

Journel AG, Huijbregts CJ (1978) Mining geostatistics. Academic Press Ltd., London, 600p.

Kengni SB, Fohouo FNT, Ngakou A (2015) Impact of the foraging activity of Apis mellifera adansonii Latreille (Hymenoptera: Apidae) and Bradyrhizobium fertilizer on pollination and yield components of Glycine $\max \mathrm{L}$. (Fabaceae) in the field. Int J Biol Res. 3(2), 64-71.

Keogh RC, Robinson APW, Mullins IJ (2005) Pollination aware: the real value of pollination in Australia. RIRDC, Australia, 73p.

Kettle WD, Taylor OR (1979) Ecological interactions of honeybees and soybeans. J Kansas Entomol Soc. 52, 549.

Kleijn D, Van Langevelde $F$ (2006) Interacting effects of landscape context and habitat quality on flower visiting insects in agricultural landscapes. Basic App Ecol. 7(3), 201-214.

Lengler, S. (1999) Princípios Básicos para Instalação de Apiário (2 ed). Departamento de Zootecnia-CCR, Santa Maria, 54p.

Lonsdorf E, Kremen C, Ricketts T, Winfree R, Williams N, et al (2009) Modelling pollination services across agricultural landscapes. Ann Bot. 103: 1589-1600.

Malerbo-Souza DT, Silva FAS (2011) Comportamento forrageiro da abelha africanizada Apis mellifera no decorrer do ano. Acta Scient An Scien. 33(2), 183-190.

Mason CE (1979) Honeybee foraging activity on soybeans in Delaware. In: International Symposium on Pollination 4. Proceedings. Micellaneous Publication, Maryland Agricultural Experiment Station, pp117-122.

Milfont MO, Rocha EEM, Lima AON, Freitas BM (2013) Higher soybean production using honeybee and wild pollinators, a sustainable alternative to pesticides and auto pollination. Environ Chem Lett. 11:335-341.
Milfont MO (2012) Uso da abelha melífera (Apis mellifera L.) na polinização e aumento de produtividade de grãos em variedade de soja (Glycine max (L.) Merril.) adaptada às condições climáticas do nordeste brasileiro. Universidade Federal do Ceará. Fortaleza, Tese de Doutorado.

Milum VG (1940) Bees and soybeans. Amer Bee J. 80, 22.

Muller L (1981) Morfologia, anatomia e desenvolvimento. In: Miyasaka, S.; Medina, J. C. (Eds.). A soja no Brasil. Instituto de Tecnologia de Alimentos, Campinas, pp73-104 Nature Editorial (2010) How to feed a hungry world. Nature 466(7306), 531-532.

Nicholson CC, Koh I, Richardson LL, Beauchemin A, Ricketts TH (2017) Farm and landscape factors interact to affect the supply of pollination services. Agriculture, Ecosystems \& Environment. 1(250):113-22.

Pufal G, Steffan-Dewenter I, Klein AM (2017) Crop pollination services at the landscape scale. Current opinion Insect Science. 1(21):91-7.

Polce $C$, Termansen $M$, Aguirre-Gutiérrez $J$, Boatman ND, Budge GE, Crowe A, Garratt MP, Pietravalle S, Potts SG, Ramirez JA, Somerwill KE, Biesmeijer JC (2013) Species Distribution Models for Crop Pollination: A Modelling Framework Applied to Great Britain. Plos One, v. 8, n. 10, e76308.

Ribeiro AMF, Couto RHN (2002) Polinização entomófila de soja (Glycine Max), Cultivar Conquista. Congresso Brasileiro de Apicultura 14. Anais. Campo Grande, 80p.

Robacker DC, Flottum PK, Sammataro D, Erickson EH (1983) Effects of climatic and edaphic factors on soybean flowers and on the subsequent attractiveness of the plants to honey bees. Field Crops Res. 6, 267-278.

Rubis DD (1970) Breeding insect pollinated crops. Ark. Agric. Ext. Serv. 127, 19-24.

Schuster I, Vieira ESN, Santana H, Sinhorati D, Silva RB, Oliveira MAR (2007) Fluxo gênico de soja na região Oeste do Paraná. Pes. Agro. Bras. 42(4) 515-520.

Sediyama T, Pereira MG, Sediyama CS, Gomes JL (1985) Cultura da soja. UFV, Viçosa, 11p.

Southwick EE, Southwick JRL (1992) Estimating the economic value of honey bees (Hymenoptera: Apidae) as agricultural pollinators in the United States. Econ. Entomol. 85, 621633.

Zanon AJ, Streck NA, Rocha TSM, Alberto CM, Bartz AC, et al (2016) Efeito do tipo de crescimento no desenvolvimento de cultivares modernas de soja após o início do florescimento no Rio Grande do Sul. Bragantia. 75(4), 446458. 